anales de psicología / annals of psychology

2019, vol. 35, no 1 (january), 148-155

http://dx.doi.org/10.6018/analesps.35.1.1326541
(C) Copyright 2019: Editum. Servicio de Publicaciones de la Universidad de Murcia. Murcia (Spain) ISSN print edition: 0212-9728. ISSN on line edition (http://revistas.um.es/analesps): 1695-2294.

On line edition License Creative Commons 4.0: BY-NC-ND

\title{
Perfectionism and sporting practice: Functional stress regulation in adolescence
}

\author{
Juan González-Hernández ${ }^{1 *}$, and Antonio Jesús Muñoz-Villena ${ }^{2}$ \\ 1 University of Granada (Spain) \\ 2 University Autonomous of Madrid (Spain)
}

\begin{abstract}
Título: Perfeccionismo y práctica deportiva. Regulación funcional del estrés en la adolescencia.

Resumen: Practicar actividad física (AF) de manera sistemática en la niñez y adolescencia, permite el desarrollo de recursos funcionales para la percepción subjetiva del bienestar, la estimulación de procesos cognitivos y de la construcción de la personalidad. Actualmente, se entiende el desarrollo de creencias perfeccionistas, como una característica funcional vinculada con aspectos positivos (afecto positivo, autoestima...), aunque en sus as pectos disfuncionales se han asociado con ansiedad y estrés. El objetivo del estudio fue identificar qué indicadores de perfeccionismo proporcionan condiciones/habilidades funcionales, que junto con el nivel de práctica de actividad física, facilitarían la regulación del estrés. Participaron 365 adolescentes (183 chicas y 182 chicos) con edades entre 13 y 17 años. Los resultados señalan que a mayor intensidad de actividad física, existen diferencias significativas en los indicadores de perfeccionismo funcional (exigencias personales y organización), respecto a facilitar (a niveles moderados) o limitar (por exceso o defecto) la percepción del estrés y sobre todo, un aumento de la intensidad en la práctica de actividad física, enfatiza patrones disfuncionales del perfeccionismo. En definitiva, la investigación ha permitido reconocer procesos psicológicos activos que influyen en una respuesta psicológica funcional o disfuncional en adolescentes, atendiendo a su perfeccionismo e intensidad de práctica de AF.
\end{abstract}

Palabras clave: Funcionalidad; Estrés percibido; Perfeccionismo; Adolescentes; Actividad física.

Regularly practising physical activity is an ideal, healthy way to obtain physical, psychological, and social benefits in the adolescent maturation process (Castillo, Balaguer, \& GarcíaMérita, 2007). The adolescent period is when the maturational development of perfectionism has been identified (Damian, Stoeber, Negru, \& Băban, 2013) and it has been recognised as an important stage for the acquisition of behaviour patterns and habits relating to health, such as systematic physical activity transferred to everyday life situations, cognitive maturation, and the perception of well-being in later developmental periods (Codina \& Pestana, 2016; González, Garcés de los Fayos, \& García del Castillo, 2011).

As the intensity of physical activity increases, individuals develop strategies and competences to cope with the circumstances surrounding them. Interacting with significant others, learning, maturing, and experimenting in their social contexts give the adolescent resources to react more or less effectively, shaping and constructing the functionalitydysfunctionality of the physical-biological condition and the psychological response linked to executive functions (MartínMartínez, Chirosa, Reigal, Hernández-Mendo, Juárez, \&

* Correspondence address [Dirección para correspondencia]: Juan González Hernández. Dpto. Personalidad, Evaluación y Tratamiento Psicológico. Facultad de Educación, Economía y Tecnología. Universidad de Granada. Campus de Ceuta, s/n, 50001 Ceuta (Spain).

E-mail: jgonzalez@,ugr.es

(Article received: 4-4-2018; revised: 10-7-2018; accepted: 23-10-2018)
Abstract: Systematic practice of physical activity (PA) in childhood and adolescence enables the development of functional resources for subjective perception of well-being, stimulation of cognitive processes, and construction of the personality. The development of perfectionist beliefs is currently seen as a functional characteristic linked to positive aspects (positive affect, self-esteem...), while its dysfunctional aspects have been associated with anxiety and stress. The aim of this study is to identify which indicators of perfectionism provide functional conditions/skills that, in combination with the level of practice of physical activity, facilitate stress regulation. A sample of 365 adolescents (183 girls and 182 boys) aged between 13 and 17 participated. The results show that as the intensity of physical activity increases, there are significant changes in the indicators for functional perfectionism (high personal standards and organisation), with reference to facilitating (at moderate levels) or limiting (if excessive or absent) perceived stress and, above all, increased intensity of physical activity accentuates dysfunctional perfectionism patterns. This research has made it possible to identify active psychological processes that influence functional or dysfunctional psychological responses in adolescents depending on their level of perfectionism and the intensity of practise of PA.

Keywords: Functionality; Perceived stress; Perfectionism; Adolescents; Physical activity.

Guisado, 2015; Wong, Lau, Wan, Cheung, Hui, \& Mok, 2013), balanced negative emotional states (Brand et al., 2017), lower levels of anxiety (Olmedilla, Ortega, \& Candel, 2010), and better psycho-social and personal maturation processes (Chaddock, Pontiflex, Hillman, \& Kramer, 2011; González \& Portolés, 2014; Ramírez, Vinaccia, \& Suárez, 2004), and consequently, the personal characteristics of the performance in question in a specific context.

Given the multidimensional conception of perfectionism in contexts of practice of physical-sporting activity (Madigan, Stoeber, \& Passfield, 2017; Stumpf \& Parker, 2000), the last two decades have seen a noticeable increase in studies that have tried to determine the association between its different dimensions, and the cognitive, emotional, and/or behavioural aspects that motivate the practice of physical activity (Hill, Hall, Appleton, \& Kozub, 2008; Longbottom, Grove, \& Dimmock, 2010). PA is regarded as functional when it is positively (and as adaptive efforts) associated with aspects such as self-efficacy, self-confidence, planning, and persistence in the physical activity (Moore et al., 2018), and dysfunctional when linked to uncertainty regarding execution, fear of failure, anxiety, and avoiding physical activity (Flett \& Hewitt, 2005). Accordingly, the relationship between efforts to achieve sporting objectives (Biddle, Wang, Kavussanu, \& Spray, 2003; Roberts, Treasure, \& Conroy, 2007) and how they are proposed, set out, and reacted to psychologically in order to achieve them (Hill \& Curran, 2016; Muñoz \& Gon- 
zález, 2017; Stoeber, Otto, Pescheck, Becker, \& Stoll, 2007; Stoeber, Stoll, Pescheck, \& Otto, 2008; Taylor, Papay, Webb, $\&$ Reeve, 2016) has become one of the most debated topics in scientific literature at present.

The response to stress in sporting practise is regarded as adaptive when it manifests itself in a constant form both in frequency and duration (Bjorklund, Blasi, \& Ellis, 2015) and as functional when it appears as an element that facilitates action (Monasterio et al., 2016). In this second case, a functional process is recognised because it creates the activation for adjusting to new conditions, and constructs subjective perceptions of psychological well-being and distress (Neil, Hanton, Mellalieu, \& Fletcher, 2011) and so of physical and mental health. Therefore, it can be claimed that the combination of processes that enable the functionality of individuals in their interaction with the environment will allow adaptive responses in terms of repeated and habituated behaviour (this is why a good comprehension of the utility of effort in adolescence enables the adapted behaviour of using physical exercise as part of one's adult lifestyle).
Based on this, humans awaken and create resources that set off functional processes as anticipatory and protective alerts in the face of situations of negative evaluation of dangers, risks to one's own life or one's physical, health, and social status (Dunkley, Berg, \& Zuroff, 2012; González \& González-Reyes, 2017; Taylor et al., 2016) or about opportunities and strengths that the consciousness can only perceive in this facilitating state of alert (Hill, Witcher, Gotwals, \& Leyland, 2015). For this reason, it is important to be able to interpret and mentally comprehend the activation (physical, physiological, and psychological) caused by the intensity of the practice of physical activity, and how this comprehension-or lack of it-creates adaptive changes (that facilitate functionality) or maladaptive reactions (that cause blocks or dysfunctionality) (see Figure 1). Perceived stress is one of these responses that is not based on the qualities of the stimulus, but rather on the perception of capacities to selfregulate personal fa ctors and the perception-interpretation of contextual factors.

\section{FUNCTIONAL-DISFUNCTIONAL PSYCHOLOGICAL RESPONSE}

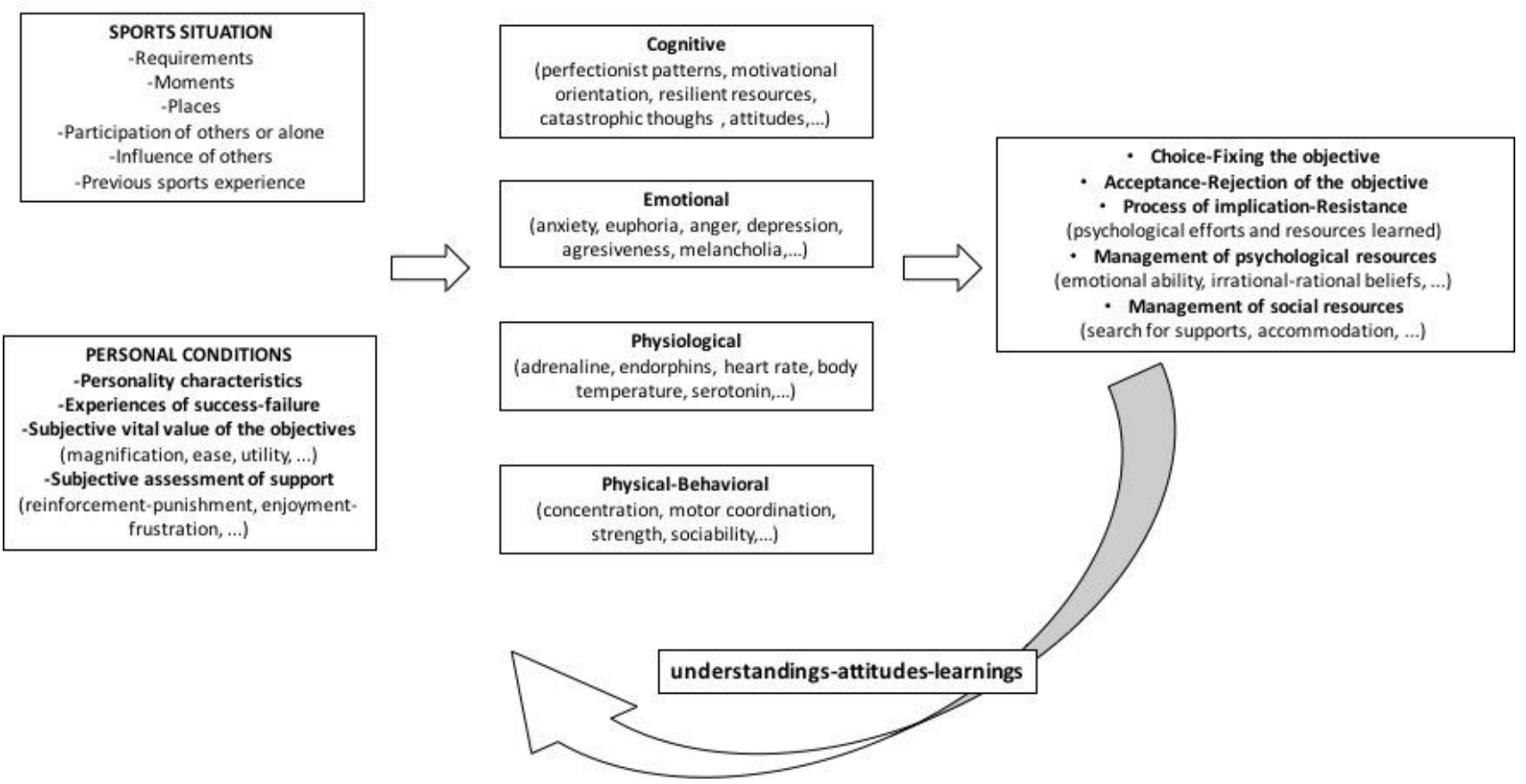

Figure 1. Functional-dysfunctional psychological response in sporting practice.

Practising physical exercise and practising sport are thought to differ in how the subjects experience the scope of their objectives. Sport (in a competitive system with governing bodies) presupposes the need for comparative efforts between the best and worst athletes, who are subject to classification and even social valuation (e.g. of the champion). Physical exercise, however, involves physical effort, through play, without it necessarily having to create high demands or a competitive requirement. Accordingly, when people practise physical exercise, and depending on the involvement of more or less perfectionist mental schemas, the perception of stress elements will allow an active response to correct identification of one's own emotions, providing a functional response that leads to higher psychological well-being and positive affective states (González et al., 2011; StultsKolehmainen \& Sinha, 2014), thus favouring mental health, 
equilibrium, and quality of the experience in sporting practice (Hamilton, Foster, \& Richards, 2016). On the other hand, a passive response (or an active response tending towards dysfunctionality) characterised by negative emotions, high physiological and emotional activation, or depressive episodes that cause mental blocks and exhaustion, will favour the perception of loss of control when faced with certain situations (Nicholls, Levy, Carson, Thompson, \& Perry, 2016), resulting in psychological distress) and loss of quality in the task being performed (Muñoz \& González, 2017; Pastor, Balaguer, Pons, \& García-Merita, 2003).

Adolescence coincides with a turbulent developmental stage, combining attention to needs in the academic setting (exams, personal and family expectations, etc.) (May \& Casazza, 2012), life changes that entail new and different social relationships (peer groups or social settings, independence from the family, etc.) (Laible, Carlo, Davis, \& Karahuta, 2016), establishing career (Negru-Subtirica \& Pop, 2016), and romantic orientations (Spinrad \& Gal, 2018), maintaining a continual physical or aesthetic condition (FernándezBustos, González-Martí, Contreras, \& Cuevas, 2015), and sometimes practising high-performance competitive sport (Molina, Chorot, Valiente, \& Sandín, 2014). Inevitably, everything set out here reveals the vulnerability of the wellbeing and distress process, and so consistent regulation of stress as a learned process involving interaction between the individual and her environment will make it possible to construct facilitating resources for a functional response to it (Breeding and Anshel, 2015; Lizmore, Dunn, \& Dunn, 2017).

In view of what has been proposed, it is interesting to know how in adolescents perfectionist beliefs are "functionalised" along with normal and balanced elements to construct psychosocial resources. This work sets out to analyse the modulating role of physical activity as a facilitator of functional patterns in the stress response among adolescents. The initial hypotheses suggest that adolescents who perform more moderate physical activity will show higher profiles for perfectionism, and that with higher levels of PA, adolescents will show higher dysfunctional patterns, and will have fewer resources for perceiving stress.

\section{Method}

\section{Participants}

This work uses, as a quantitative and non-random methodology, a cross-sectional, correlational, and predictive design. The sample comprises 365 adolescents from different communities in the provinces of Madrid and Granada (Spain), aged between 13 and $17(M=15.02 ; S D=1.36)$. Their age distribution is: 13 (29\%), 14 (14.8\%), $15(14.8 \%)$, $16(18.9 \%)$, and $17(22.5 \%)$. Of the participants, 182 were male $(49.86 \%)$ and 183 female (50.14\%). They were from families with a medium-high socioeconomic level.

\section{Instruments}

Ad-hoc sociodemographic and sport frequency questionnaire This is a self-administered questionnaire comprising four items. It was prepared by the researchers based on the WHO's PAQA methodology. The questionnaire compiles information relating to the intensity of subjects' PA (non-vigorous [low, moderate] and vigorous) and how frequently they play sports (sport played and number of days). The answer format takes into account personal variables regarding age, gender, studies, and socioeconomic level relating to the information being studied.

Frost Multidimensional Perfectionism Scale (FMPS; Frost, Marten, Lahart, \& Rosenblate, 1990, version adapted for use with Spanish populations by Carrasco, Belloch, \& Perpiñá, 2010). The items are distributed across two secondorder dimensions, made up of second-order indicators: functional perfectionism (achievement expectations and organisation) and dysfunctional perfectionism (fear of mistakes and parental influences). The scale comprises 35 items, measured on a five point Likert scale, from 1 ("strongly agree") to 5 ("strongly disagree"). Regarding the internal consistency of this sample, $\alpha$ values of between .89 (organisation) and .82 (paternal influence) were found. These are very similar to those from the other studies performed.

Perceived Stress Scale (PSS; Cohen, Kamarck, \& Mermelstein, 1983, version adapted for use with Spanish populations by Remor \& Carrobles, 2001). This comprises 14 items ( 7 positively phrased and 7 negatively phrased), measured on a Likert scale from 0 ("never") to 4 ("very often"), giving a single indicator called perceived stress, where the higher the figure, the greater the perception of stress, with a Cronbach's alpha of .81 for internal consistency.

\section{Procedure}

To carry out this research, sport and education centres were contacted to request permission from their management (coaches and teachers in charge of the centres) and the aim of the research and the method for obtaining and protecting data were explained to them. They were given an informed consent protocol which the adolescents had to give to their legal guardians to complete, in accordance with the Helsinki regulations. Once permission had been obtained, the contacted centres were visited again and the adolescents who had given accepted informed consent were asked to participate voluntarily in the study and were informed of the confidentiality and anonymity of the data. At this point, the questionnaires were administered collectively in the classroom for a period of 30 minutes without interruption. A researcher was present at all times during data collection to ensure possible contaminating distractions were controlled and solve any doubts if required. 


\section{Data analysis}

The codification and processing of the data was done using the SPSS 22.0 for Windows statistics package. Analyses of the internal reliability of the measurements used were performed (Cronbach's alpha), as well as descriptive analysis (mean, standard deviation), the normal distribution was checked for (Kolmogorov-Smirnov), and comparative measurements were performed ( $t$ test for differences in means between groups and Cohen's d for effect size). For the predictive relationships, multiple stepwise regression analyses and moderated mediation analyses were performed $\left(\mathrm{VI}_{\text {ndependent }}\right.$ : perfectionism; $\mathrm{VD}_{\text {ependent }}$ : perception of stress; $\mathrm{VM}_{\text {oderate }}$ practising physical activity) using the PROCESS program.

\section{Results}

\section{Differential analysis}

The frequency of physical activity by gender of participants (Table 1), shows that girls practise more $\mathrm{PA}_{\mathrm{NonVigorous}}$ than boys, while boys practise more $\mathrm{PA}_{\text {Vigorous. }}$ Furthermore, it is apparent that as their age increases, girls practise less PA, while boys practise less $\mathrm{PA}_{\mathrm{NonVigorous}}$ and more $\mathrm{P} \mathrm{V}_{V_{\text {igorous }}}$.

Table 1. Gender and age distribution in Physical Activity practice.

\begin{tabular}{|c|c|c|c|c|c|}
\hline \multirow[t]{2}{*}{$N=365$} & & \multicolumn{2}{|c|}{$\begin{array}{c}\mathrm{PA}_{\text {NonVigorous }} \\
(n=165)\end{array}$} & \multicolumn{2}{|c|}{$\begin{array}{l}\text { PA } \\
(n=200)\end{array}$} \\
\hline & & Male & Female & Male & Female \\
\hline \multirow{6}{*}{ Age } & 13 & 14 & 33 & 28 & 31 \\
\hline & 14 & 6 & 18 & 22 & 8 \\
\hline & 15 & 4 & 17 & 19 & 14 \\
\hline & 16 & 21 & 26 & 19 & 3 \\
\hline & 17 & 13 & 13 & 36 & 20 \\
\hline & & 58 & 107 & 124 & 76 \\
\hline
\end{tabular}

The means for the indicators of perfectionism and perceived stress as a function of sporting frequency (nonvigorous or vigorous) (Table 2) show, with a large effect size, that the higher the more frequent physical activity is, the higher the mean scores for all indicators of perfectionism are, These are significant in the case of organisation $\left(t_{(363.2)}\right.$ $=-2.72 ; p=.00)$, personal standards $\left(t_{(363.2)}=-3.73\right.$; $p=.00)$, and fear of mistakes $\left(t_{(363.2)}=-14.31 ; p=.02\right)$.

$\underline{\text { Table 2. Perfectionism and perceived stress indicators by frequency of PA. }}$

\begin{tabular}{|c|c|c|c|c|c|c|c|}
\hline \multirow[t]{2}{*}{$N=365$} & \multirow[b]{2}{*}{ K-S } & \multicolumn{2}{|c|}{$\begin{array}{c}\mathrm{PA}_{\text {NonVigorous }} \\
(n=165)\end{array}$} & \multicolumn{2}{|c|}{$\begin{array}{l}\mathrm{PA}_{\text {Vigorous }} \\
(n=200)\end{array}$} & \multirow[t]{2}{*}{$p$} & \multirow[t]{2}{*}{$d$} \\
\hline & & $M$ & $S D$ & $M$ & $S D$ & & \\
\hline Organization & .21 & 21.31 & 6.21 & 24.53 & 3.31 & $.00^{* *}$ & .52 \\
\hline Personal standards & .24 & 23.84 & 4.30 & 26.84 & 4.63 & $.00^{* *}$ & .48 \\
\hline Fear of mistakes & .31 & 23.95 & 6.53 & 25.04 & 3.45 & $.02^{*}$ & .36 \\
\hline Parental influences & .34 & 20.51 & 5.20 & 21.12 & 3.51 & .42 & .63 \\
\hline Perceived stress & .33 & 24.73 & 5.04 & 25.38 & 4.26 & .21 & .41 \\
\hline
\end{tabular}

***ignificant if $p<.05$

\section{Predictive analyses}

The predictive analysis constructs two stress perception models (Table 3). The first one $\left(F_{(125.1)}=27.44 ; p<.00\right)$, with an explained variance of $38 \%$, shows that only an increase in perceived fear of mistakes make perceived stress increase. The second one $\left(F_{(124.2)}=17.65 ; p<.00\right)$, which has an explained variation of $22 \%$, shows that the perception of stress in the group of adolescents is predictive of an increase in age, greater intensity in practice of $\mathrm{PA}$, and the perception of fear of making mistakes, and does not create any predictive relationship with the functional indicators of perfectionism.

In the same way, two other predictive models for intensity of PA practice were established. The first one $\left(F_{(125.1)}=19.81 ; p<.01\right)$, with an explained variation of $33 \%$, reflects the fact that setting high personal standards positively predicts an increase in intensity of practice of PA. A second model $\left(F_{(124,2)}=21.62 ; p<.00\right)$ predicts with a variance of $24 \%$ that the combination of increased personal standards and reduced fear of making mistakes predicts an increase in the intensity of practise of physical activity in adolescents.
Table 3. Predictive (stepwise) model of perceived stress and intensity of practice of PA.

\begin{tabular}{|c|c|c|c|c|}
\hline Model 1 & $\mathrm{R}^{2}$ & $\beta$ & $F$ & $p$ \\
\hline VD $=$ Perceived stress & .42 & .38 & 27.44 & $.00^{* *}$ \\
\hline \multicolumn{5}{|l|}{ Step 1} \\
\hline \multicolumn{5}{|l|}{ Fear of mistakes $(B=.42 ; p<.00)$} \\
\hline & .47 & .22 & 17.65 & $.00 * *$ \\
\hline \multicolumn{5}{|l|}{ Step 2} \\
\hline \multicolumn{5}{|l|}{ Fear of mistakes $(B=.40 ; p<.00)$} \\
\hline \multicolumn{5}{|l|}{ Age $\quad(B=.21 ; p<.00)$} \\
\hline \multicolumn{5}{|l|}{ Intensity of PA $\quad(B=.34 ; p<.01)$} \\
\hline Model 2 & $\mathrm{R}^{2}$ & $\beta$ & $F$ & $p$ \\
\hline $\mathrm{VD}=$ Intensity practice of PA & .35 & .33 & 19.81 & $.01 *$ \\
\hline \multicolumn{5}{|l|}{ Step 1} \\
\hline \multicolumn{5}{|l|}{ Personal standards $(\beta=.34 ; p<.02)$} \\
\hline & .47 & .24 & 21.62 & $.00 * *$ \\
\hline
\end{tabular}

\section{Step 2}

Personal standards $(B=.42 ; p<.02)$

Fear of mistakes $\quad(\beta=-.32 ; p<.00)$

* ${ }^{*}$ ignificant if $p<.05 ;{ }^{* *}$ significant if $p<.01$.

Running the moderated analysis shows that adaptive perfectionism (personal standards and organisation) along with practice of $\mathrm{PA}_{\mathrm{NonVigorous}}$ establishes an inverse predictive rela- 
tionship with high perceptions of stress. With $\mathrm{PA}_{\text {Moderate }}$ the perception of stress becomes accustomed and maintained (Figure 2), so that perfectionism only responds functionally with lower stress indicators being perceived when the practice is daily, of normal and non-vigorous intensity.

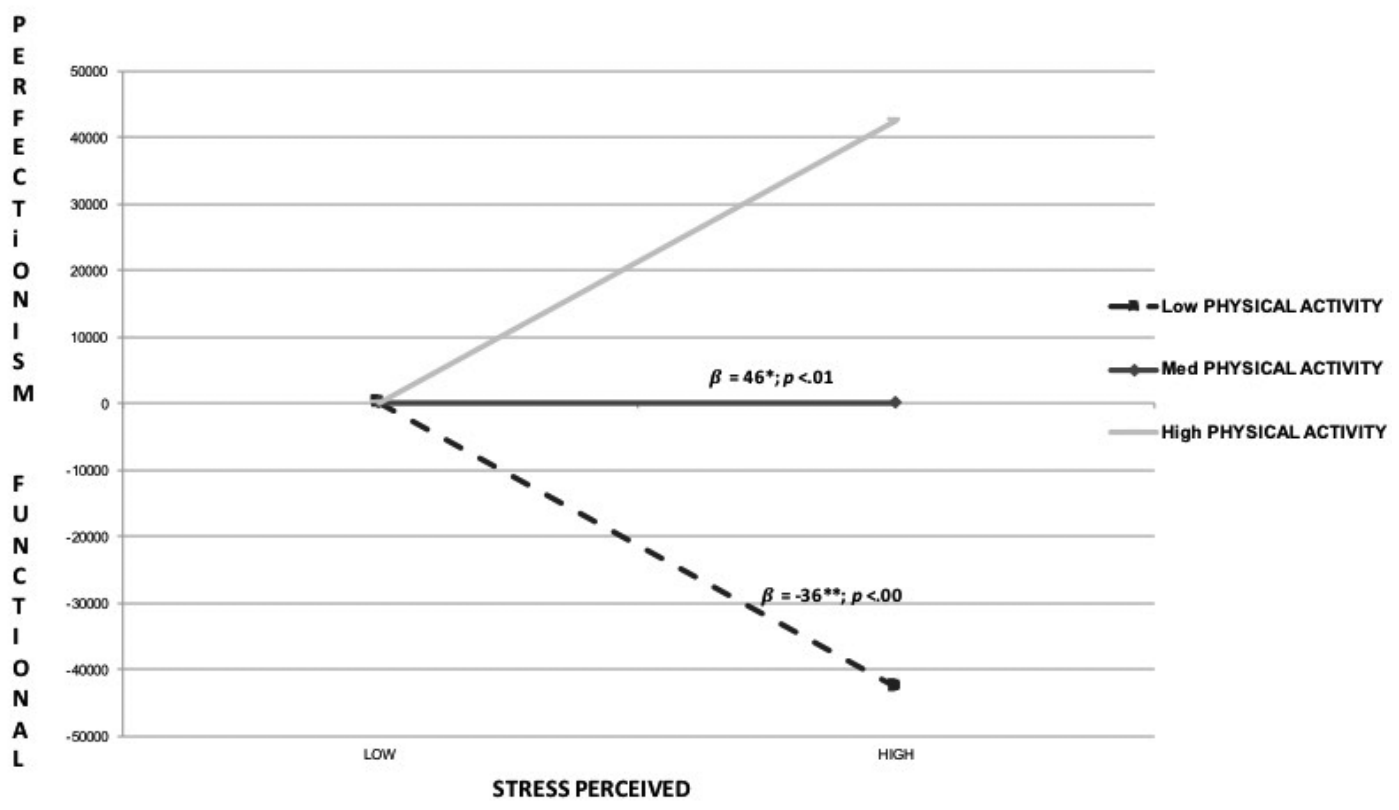

Figure 2. Moderated mediation analysis functional perfectionism.

Applying the moderator analysis shows that maladaptive perfectionism (fear of mistakes and concern over actions) in combination with increased practise of physical activity (PAM ${ }_{\text {oderate }}$ and $\mathrm{PAV}$ igorous) establishes relationships with high perceptions of stress (Figure 3). In this way, maladaptive per- fectionism responds dysfunctionally resulting in a higher perception of stress indicators when the sample of adolescents analysed reports an increase in the intensity of their PA practice.

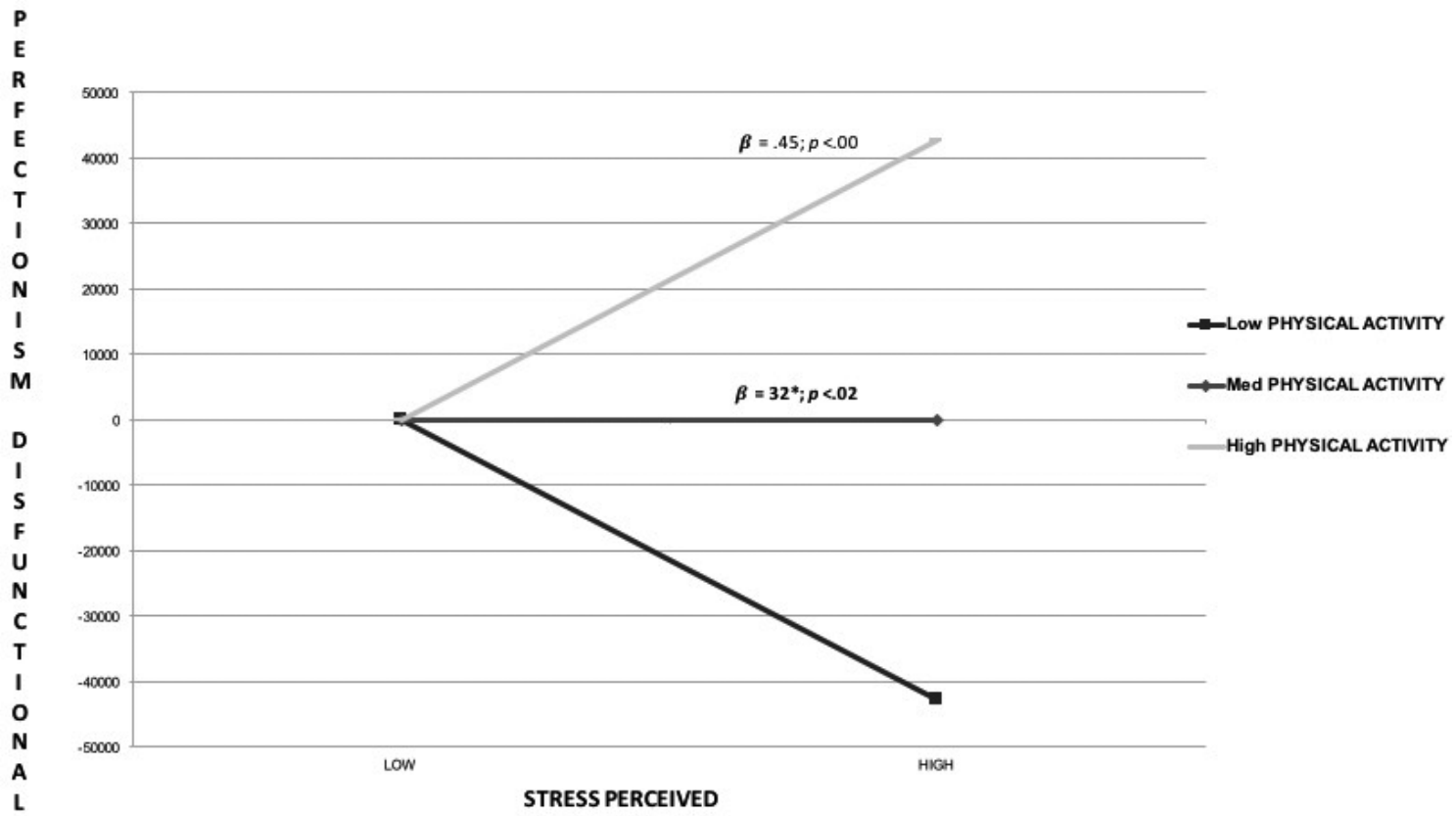

Figure 3. Moderated mediation analysis Dysfunctional perfectionism. 
As booth images show, there are no significant levels of predictability when the intensity is $\mathrm{PA}_{\text {Low }}$, and so this variable has been considered in combination with non-vigorous PA.

\section{Discussion}

This work sets out to describe perfectionist patterns of behaviour along with intensity of PA practice, establishing their relationship for maintaining functional or dysfunctional levels of perceived stress in a sample of adolescents.

The description of the sample showed that regular practice of PA in adolescence falls gradually as adolescence progresses, despite the annual recommendations of the WHO. This negative trend in frequency of PA in higher academic years (also corresponding to age) coincides with the point in life where PA stops being obligatory or significant in the curriculum, and has previously been identified in studies that have shown similar results in adolescent populations in Spain (Codina \& Pestana, 2016), anglosajon world (Peetz, Buehler, $\&$ Britten, 2011), and South America (Bolaños, Cornejo, Rocha, Vitoria, Flores, \& Campos, 2016). Another important piece of data is the difference in practice of PA by gender, with boys being more involved in vigorous PA, as shown in other previous studies (González \& Portolés, 2014; Práxedes, Sevil, Moreno, Del Villar, \& García-González, 2016).

The first starting hypothesis suggests that adolescents with the highest demands in sporting practice will show higher indicators of perfectionism. The comparison of means between the study variables shows significant differences in the more functional indicators of perfectionism (organisation and personal standards) in favour of those who

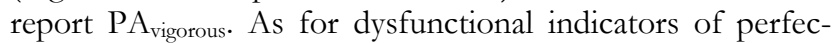
tionism (parental expectations and fear of mistakes), a tendency to increase with medium or higher intensity of PA is apparent, as is a positive and significant relationship with perceived stress. These results agree with others identified (Gotwals, Stoeber, Dunn, \& Stoll., 2012; McMahon et al., 2017), and they are associated with the appearance of psychological risks deriving from exercise that is excessive in duration and intensity ( $\left.\mathrm{PA}_{\text {vigorous }}\right)$. They also agree with studies that state they focus on the negative evaluation of resources for facing the demands of the social context surrounding this activity (Schwebel, Smith, \& Smoll, 2016; Taylor et al., 2016).

Results of the predictive analysis show that practising PA is positively related with the mental establishment of personal standards and with reduced fear of mistakes. Accordingly, when adolescents increase the intensity of practice of $\mathrm{PA}$, it is regarded as very important to train or educate the adolescents so that they set certain balanced standards of requirement for themselves and develop beliefs for to increase capacities and that allow to reduce fear of mistakes (demystifying mistakes). Results obtained suggest that intensifying PA practice means that adolescents with maladaptive perfectionist profiles identify higher significant levels of perceived stress, thus provoking a positive stress stimulus (Molina et al., 2014) and a psychosocial resource for the dysfunctional response in the face of the response in question (Cairney, Kwan, Veldhuizen, \& Faulkner, 2014; Remor \& PérezLlantada, 2007). Significant relevance is only found in adolescents with adaptive perfectionist profiles when the intensity of PA is vigorous, given that the high standards mentioned above are also associated with higher demands in sporting activities.

In contrast, maintaining moderate intensity of PA (brisk walking, dancing, active participation in games and sports, walking with pets, carrying moderate loads of under $20 \mathrm{~kg}$ ) shows a direct and significant relationship with the more adaptive processes of the perfectionist pattern, with the result that this process, which is between habit and belief, facilitates the regulatory and functional perception of the stress response.

The second of the hypotheses states that as levels of intensity of practice of PA increase, adolescents will show greater dysfunctional patterns and have fewer resources for perceiving stress. The results obtained confirm that those subjects with tendencies towards fear of making mistakes and a perception of pressure from parental influences and expectations report a higher perception of the stress response as the intensity of PA increases, with something similar also being shown by other studies with samples of young sportspeople, both competitive (Gustafsson, Hill, Stenling, \& Wagnsson, 2016) and non-competitive (Franche \& Gaudreau, 2016).

\section{Conclusions}

This work has attempted to establish how relevant is the construction of perfectionist beliefs about tasks (in this case sporting ones) in adolescence. The aim of this was to test whether these beliefs behave functionally or dysfunctionally when performing the tasks (that is, they are not just configured mentally also corroborated when put into practice). A large sample of Spanish adolescents was contacted in order to administer surveys to them and it was found that for adolescents who focus on their concerns and the perception of external pressures, there is an increase in the perception of stress both through practising $\mathrm{PA}_{\text {Vigorous }}$ and $\mathrm{PA}_{\text {Moderate. In }}$ contrast, for adolescents with perfectionist patterns built on the basis of balanced requirements and ordered planning, practising $\mathrm{PA}_{\text {Moderate }}$ allows for the functional response (perceiving less stress), while practising $\mathrm{PA}_{\text {Low }}$ has an inverse predictive relationship on the increased perception of stress. These results show that PA practice which is unbalanced in frequency and intensity ( $\left.\mathrm{PAV} \mathrm{V}_{\text {igorous }}\right)$ does not significantly result in an improvement in stress regulation when adolescents put into play their more functional resources on the beliefs about how to act.

Having shown the importance of practising physical activity for indicators of perfectionism and perceived stress, fu- 
ture research with other age cohorts, in other socioeconomic contexts, using tests that are better understood in the adolescent period and combining other methodologies such as collecting information qualitatively through focus groups or indepth interviews is advisable. Similarly, taking into account other aspects that affect the construction of perfectionist beliefs (e.g. personality traits, coping resources, perceived social support, etc.), would make it possible to examine in greater depth how many of these schema are associated with ongoing sporting practice, their functional-dysfunctional experiences and responses, or to resistance to effort, including giving up sport. Similarly, establishing experimental and pseudo-experimental methodologies that allow longitudinal continuity and continuity over time in the measurements will make it possible to explain whether the answers obtained here are repeated, whether they are typical of an era or specific events restricted to adolescence, or whether they change with the passage of time and maturation or new experiences.

\section{References}

Biddle, S., Wang, C. J., Kavussanu, M., \& Spray, C. (2003). Correlates of achievement goal orientations in physical activity: A systematic review of research. European Journal of Sport Science, 3(5), 1-20. http://dx.doi.org/10.1080/17461390300073504

Bolaños, M. C., Cornejo, J. M., Rocha, C. L., Vitoria, R. V., Flores, B. C., \& Campos, R. G. (2016). Patrones de actividad física de adolescentes escolares: validez, confiabilidad y propuesta de percentiles para su evaluación. Revista Chilena de Pediatría. https://doi.org/10.1016/j.rchipe.2016.07.010

Bjorklund, D. F., Blasi, C. H., \& Ellis, B. J. (2015). Evolutionary developmental psychology. The Handbook of Evolutionary Psychology, 1-21. doi.org/10.1002/9781119125563.evpsych238

Brand, S., Kalak, N., Gerber, M., Clough, P. J., Lemola, S., Sadeghi Bahmani, D., Püshe, U., \& Holsboer-Trachsler, E. (2017). During early to mid adolescence, moderate to vigorous physical activity is associated with restoring sleep, psychological functioning, mental toughness and male gender. Journal of Sports Sciences, 35(5), 426-434. DOI: 10.1080/02640414.2016.1167936

Breeding, T. W., \& Anshel, M. H. (2015). Relationship between sport perfectionism and perceived competence as a function of skill level and sport type. Journal of Sport Behavior, 38(4), 37

Cairney, J., Kwan, M.Y., Veldhuizen, S., \& Faulkner, G.E. (2014). Who uses exercise as a coping strategy for stress? Results from a national survey of Canadians. Journal of Physical Activity and Health, 11(5), 908-9016. https://doi.org/10.1123/jpah.2012-0107

Carrasco, A., Belloch, A., \& Perpiñá. C. (2010). La evaluación del perfeccionismo: utilidad de la Escala Multidimensional de Perfeccionismo en población española. Análisis de Modificación de Conducta, 36(153), 49-65.

Castillo, I., Balaguer, I., \& García-Mérita, M. (2007). Efecto de la práctica de actividad física y de la participación deportiva sobre el estilo de vida saludable en la adolescencia en función del género. Revista de Psicología del Deporte, 16(2), 201-210.

Chaddock, L., Pontiflex, M. B., Hillman, C. H., \& Kramer, A. F. (2011). A review of the relation of aerobic fitness and physical activity to brain structure and function in children. Journal of the International Neuropsychological Society, 17, 975-985. Doi: http://dx.doi.org/10.1017/s1355617711000567

Codina, N., \& Pestana, J. V. (2016). Actividad físico-deportiva como experiencia de ocio y Perspectiva Temporal en los jóvenes. Revista de Psicología del Deporte, 25(2), 53-60.

Cohen, S., Kamarck, T., \& Mermelstein, R. (1983). A global measure of perceived stress. Journal of Health and Social Behavior, 24, 385-396. http://dx.doi.org/10.2307/2136404
The data provided, should be considered in light of the existence of limitations that did not allow access to a broader sample of adolescents or continuing the measurements in another later measurement $\left(\mathrm{T}_{2}\right)$. Despite these limitations, the research makes an important contribution to understanding psychological responses in adolescents relating to their sporting practice and their beliefs about the levels of requirement of their pursuits and their personal resources, a topic that has been of great importance in the last two decades in sporting, educational, and clinical settings. Evaluating this type of variable makes it possible to design preventative health programmes and/or programmes for stimulating coping strategies that, maintained over time, become more adaptive. It also enables training in cognitive and emotional selfregulation skills, learning about psychological resources (e.g. motivational counselling or self-talk), which combined with healthy habits such as practising balanced PA helps confront stressful situations effectively and functionally.

Damian, L.E., Stoeber, J., Negru, O., \& Băban, A. (2013). On the development of perfectionism in adolescence: Perceived parental expectations predict longitudinal increases in socially prescribed perfectionism. Per sonality and Individual Differences, 55(6), 688-693. https://doi.org/10.1016/j.paid.2013.05.021

Dunkley, D. M., Berg, J. L., \& Zuroff, D. C. (2012). The role of perfectionism in daily self- esteem, attachment, and negative affect. Journal of Personality, 80(3), 633-663. DOI: 10.1111/j.1467-6494.2011.00741.x

Fernández-Bustos, J. G., González-Martí, I., Contreras, O., \& Cuevas, R. (2015). Relación entre imagen corporal y autoconcepto físico en mujeres adolescentes. Revista Latinoamericana de Psicología, 47(1), 25-33.

Flett, G. L., \& Hewitt, P. L. (2005). The perils of perfectionism in sports and exercise. Current Directions in Psychological Science, 14(1), 14-18. http://dx.doi.org/10.1111/j.0963-7214.2005.00326.x

Franche, V., \& Gaudreau, P. (2016). Integrating dispositional perfectionism and within-person variations of perfectionism across life domains into a multilevel extension of the $2 \times 2$ model of perfectionism. Personalit $\begin{array}{llr}\text { and Individual } & \text { Differences, } & \text { 59, }\end{array}$ https://doi.org/10.1016/j.paid.2015.09.046

Frost, R.O., Marten, P., Lahart, C., \& Rosenblate, R. (1990). The dimensions of perfectionism. Cognitive Therapy and Research, 14(5), 449-468. http://dx.doi.org/10.1007/BF01172967

González, J., Garcés de los Fayos, E. J., \& García del Castillo, A. (2011). Percepción de bienestar psicológico y fomento de la práctica de actividad física en población adolescente. Revista Internacional de Ciencias Sociales y Humanidades, 21(2), 55-71.

González, J., \& González-Reyes, A. (2017). Perfeccionismo y "alarma adaptativa" a la ansiedad en deportes de combate. Revista de Psicología del Deporte, 26(2), 15-23.

González, J., \& Portolés, A. (2014). Actividad física extraescolar: relaciones con la motivación educativa, rendimiento académico y conductas asociadas a la salud. Revista Iberoamericana de Psicología del Ejercicio y el Deporte, 9(1), 51-65.

Gotwals, J. K., Stoeber, J., Dunn, J. G. H., \& Stoll, O. (2012). Are perfectionistic strivings in sport adaptive? A systematic review of confirmatory, contradictory, and mixedevidence. Canadian Psychology, 53(4), 263 279. http://dx.doi.org/10.1037/a0030288

Gustafsson, H., Hill, A. P., Stenling, A., \& Wagnsson, S. (2016). Profiles of perfectionism, parental climate, and burnout among competitive junior athletes. Scandinavian journal of Medicine y Science in Sports, 26(10), 12561264. http://dx.doi.org/10.1111/sms.12553 
Hamilton, A., Foster, C., \& Richards, J. (2016). A systematic review of the mental health impacts of sport and physical activity programmes for adolescents in post-conflict settings. Journal Sport Dev, 4, 44-59.

Hill, A. P., \& Curran, T. (2016). Multidimensional perfectionism and burnout: A meta-analysis. Personality and Social Psychology Review, 20(3), 269288. http://dx.doi.org/10.1177/1088868315596286

Hill, A. P., Hall, H. K., Appleton, P. R., \& Kozub, S. A. (2008). Perfectionism and burnout in junior elite soccer players: The mediating influence of unconditional self-acceptance. Psychology of Sport and Exercise, 9(5), 630-644. http://dx.doi.org/10.1016/i.psychsport.2007.09.004

Hill, A. P., Witcher, C. S., Gotwals, J. K., \& Leyland, A. F. (2015). A qualitative study of perfectionism among self-identified perfectionists in sport and the performing arts. Sport, Exercise, and Performance Psychology, 4(4), 237. http://dx.doi.org/10.1037/spy0000041

Laible, D., Carlo, G., Davis, A. N., \& Karahuta, E. (2016). Maternal sensitivity and effortful control in early childhood as predictors of adolescents' adjustment: The mediating roles of peer group affiliation and social behaviors. Developmental Psychology, 52(6), 922. doi:10.1037/dev0000118

Lizmore, M. R., Dunn, J. G., \& Dunn, J. C. (2017). Perfectionistic strivings, perfectionistic concerns, and reactions to poor personal performances among intercollegiate athletes. Psychology of Sport and Exercise, 33, 75-84. http://dx.doi.org/10.1016/j.psychsport.2017.07.010

Longbottom, J.L., Grove, J. R., \& Dimmock. J.A. (2010). An examination of perfectionism traits and physical activity motivation. Psychology of Sport and Exercise, 11, 574-581. http://dx.doi.org/10.1016/j.psychsport.2010.06.007

Madigan, D. J., Stoeber, J., \& Passfield, L. (2017). Perfectionism and achievement goals revisited: The $3 \times 2$ achievement goal framework. Psychology of Sport and Exercise, 28, 120-124. https://doi.org/10.1016/j.psychsport.2016.10.008

Martín-Martínez, I., Chirosa-Ríos, L. J., Reigal-Garrido, R. E., HernándezMendo, A., Juárez-Ruiz-de-Mier, R., \& Guisado-Barrilao, R. (2015). Efectos de la actividad física sobre las funciones ejecutivas en una muestra de adolescentes. Anales de Psicologia, 31(3), 962-971. https://doi.org/10.6018/analesps.32.1.171601

May, R. W., \& Casazza, S. P. (2012). Academic major as a perceived stress indicator: Extending stress management intervention. College Student Journal, 264-273.

McMahon, E. M., Corcoran, P., O’Regan, G., Keeley, H., Cannon, M., Carli, V., \& Balazs, J. (2017). Physical activity in European adolescents and associations with anxiety, depression and well-being. European Child $y$ Adolescent Psychiatry, 26(1), 111-122. http://dx.doi.org/10.1007/s00787016-0875-9

Molina, J., Chorot, P., Valiente, R. M., \& Sandín, B. (2014). Miedo a la evaluación negativa, autoestima y presión psicológica: Efectos sobre el rendimiento deportivo en adolescentes. Cuadernos de Psicología del Deporte, 14(3), 57-66

Monasterio, E., Mei-Dan, O., Hackney, A. C., Lane, A. R., Zwir, I., Rozsa, S., \& Cloninger, C. R. (2016). Stress reactivity and personality in extreme sport athletes: The psychobiology of BASE jumpers. Physiology y Behavior, 167,

289-297. http://dx.doi.org/10.1016/j.physbeh.2016.09.025

Moore, E., Holding, A. C., Hope, N. H., Harvey, B., Powers, T. A., Zuroff, D., \& Koestner, R. (2018). Perfectionism and the pursuit of personal goals: A self-determination theory analysis. Motivation and Emotion, 42(1), 37-49. http://dx.doi.org/10.1007/s11031-017-9654-2

Muñoz, A. J., \& González, J. (2017). Percepción de estrés y perfeccionismo en estudiantes adolescentes. Influencias de la actividad física y el género. Ansiedad y Estrés, 23(1), 32-37. https://doi.org/10.1016/j.anyes.2017.04.001

Negru-Subtirica, O., \& Pop, E. I. (2016). Longitudinal links between career adaptability and academic achievement in adolescence. Journal of Vocational Behavior, 93, 163-170.

Neil, R., Hanton, S., Mellalieu, S. D., \& Fletcher, D. (2011). Competition stress and emotions in sport performers: The role of further appraisals. Psychology of Sport and Exercise, 12(4), 460-470. http://dx.doi.org/10.1016/j.psychsport.2011.02.001
Nicholls, A. R., Levy, A. R., Carson, F., Thompson, M. A., \& Perry, J. L. (2016). The applicability of self-regulation theories in sport: goal adjustment capacities, stress appraisals, coping, and well-being among athletes. Psychology of Sport and Exercise, 27, 47-55. http://dx.doi.org/10.1016/j.psychsport.2016.07.011

Olmedilla, A., Ortega, E., \& Candel, N. (2010). Ansiedad, depresión y práctica de ejercicio físico en estudiantes universitarias. ApuntsMedEsport, 45(167), 175-180

Pastor, Y., Balaguer, I., Pons, D., \& García-Merita, M. (2003). Testing direct and indirect effects of sports participation on perceived health in Spanish adolescents between 15 and 18 years of age. Journal of Adolescence, 26, 717-730. http://dx.doi.org/10.1016/j.adolescence.2003.07.001

Peetz, J., Buehler, R., \& Britten, K. (2011). Only minutes-a-day: Reframing exercise duration affects exercise intention and behavior. Basic and $A p$ plied Social Psychology, $33, \quad 118-127$. http://dx.doi.org/10.1080/01973533.2011.568870

Práxedes, A., Sevil, J., Moreno, A., Del Villar, F., \& García-González, L. (2016). Niveles de actividad física en estudiantes universitarios: diferencias en función del género, la edad y los estados de cambio. Revista Iberoamericana de Psicología del Ejercicio y el Deporte, 11(1)

Ramírez, W., Vinaccia, S., \& Suárez, G.R. (2004). El impacto de la actividad física y el deporte sobre la salud, la cognición, la socialización y el rendimiento académico: una revisión teórica. Revista de Estudios Sociales, 18, 67-75.

Remor, E., \& Carrobles, J.A. (2001). Versión Española de la escala de estrés percibido (PSS-14): Estudio psicométrico en una muestra VIH+. Ansiedad y Estrés, 7(2-3), 195-201.

Remor, E., \& Pérez-Llantada, M. C. (2007). La relación entre niveles de la Actividad Física y la Experiencia de Estrés y de síntomas de malestar físico. Interamerican Journal of Psychology, 41(3), 313-322.

Roberts, G. C., Treasure, D. C., \& Conroy, D. E. (2007). Understanding the dynamics of motivation in sport and physical activity: An achievement goal interpretation. Handbook of Sport Psychology, Third Edition, 1-30. http://dx.doi.org/10.1002/9781118270011.ch1

Schwebel, F. J., Smith, R. E., \& Smoll, F. L. (2016). Measurement of perceived parental success standards in sport and relations with athletes' self-esteem, performance anxiety, and achievement goal orientation: Comparing parental and coach influences. Child Development Research, 2016. http://dx.doi.org/10.1155/2016/7056075

Spinrad, T. L., \& Gal, D. E. (2018). Fostering prosocial behavior and empathy in young children. Current Opinion in Psychology, 20, 40-44. http://dx.doi.org/10.1016/j.copsyc.2017.08.004

Stoeber, J., Otto, K., Pescheck, E., Becker, C., \& Stoll, O. (2007). Perfectionism and competitive anxiety in athletes: Differentiating striving for perfection and negative reactions to imperfection. Personality and Individual Differences, 42(6), 959-969. http://dx.doi.org/10.1016/j.paid.2006.09.006

Stoeber, J., Stoll, O., Pescheck, E., \& Otto, K. (2008). Perfectionism and achievement goals in athletes: Relations with approach and avoidance orientations in mastery and performance goals. Psychology of Sport and Exercise, 9(2), 102-121. http://dx.doi.org/10.1016/j.psychsport.2007.02.002

Stults-Kolehmainen, M. A., \& Sinha, R. (2014). The effects of stress on physical activity and exercise. Sports Medicine, 44(1), 81-121.

Stumpf, H., \& Parker, W. D. (2000). A hierarchical structural analysis of perfectionism and its relation to other personality characteristics. Personality and Individual Differences, 28(5), 837-852. http:/ /dx.doi.org/10.1016/S0191-8869(99)00141-5

Taylor, J., Papay, K., Webb, J., \& Reeve, C. (2016). The good, the bad, and the interactive: evaluative concerns perfectionism moderates the effect of personal strivings perfectionism on self-esteem. Personality and Individual differences, 95, 1-5. http://dx.doi.org/10.1016/j.paid.2016.02.006

Wong, M. L., Lau, E. Y. Y., Wan, J. H. Y., Cheung, S. F., Hui, C. H., \& Mok, D. S. Y. (2013). The interplay between sleep and mood in predicting academic functioning, physical health and psychological health: a longitudinal study. Journal of Psychosomatic Research,74, 271-277. doi:10.1016/j.jpsychores.2012.08.014. 